\title{
Discussion session: biomarker trials
}

Various speakers

From 3rd International Clinical Trials Methodology Conference

Glasgow, UK. 16-17 November 2015

Various speakers In a combined presentation and discussion session, representatives from academia and industry discuss the role of Biomarker trial design and implementation, to improve health by improving trials.

Published: 16 November 2015

doi:10.1186/1745-6215-16-S2-I2

Cite this article as: : Discussion session: biomarker trials. Trials 2015

16(Suppl 2):12.

Submit your next manuscript to BioMed Central and take full advantage of:

- Convenient online submission

- Thorough peer review

- No space constraints or color figure charges

- Immediate publication on acceptance

- Inclusion in PubMed, CAS, Scopus and Google Scholar

- Research which is freely available for redistribution

Submit your manuscript at

www.biomedcentral.com/submit

\section{() Biomed Central}

